\title{
The Relationship between Perceived Emotional Intelligence, Work Engagement, Job Satisfaction, and Burnout in Italian School Teachers: An Exploratory Study
}

\author{
Antonella D’Amico, Alessandro Geraci, and Chiara Tarantino \\ University of Palermo, Department of Psychology, Educational Science and \\ Human Movement, Palermo, Italy
}

\begin{abstract}
The study investigates the relationship between perceived emotional intelligence, burnout, work engagement, and job satisfaction in 238 Italian school teachers. The mean age was 50 years, ranged from 26 to $66(S D=9.16)$. The research protocol included a demographics data sheet, the Wong and Law Emotional Intelligence Scale (WLEIS; Wong \& Law, 2002), the Copenhagen Burnout Inventory (CBI; Kristensen, Borritz, Villadsen, \& Christensen, 2005), the Utrecht Work Engagement Scale (UWES; Schaufeli, Bakker, \& Salanova, 2006), and the Organizational Satisfaction Scale (QSO; Cortese, 2001). Several international studies already demonstrated an association among these variables. Our results showed that perceived emotional intelligence positively correlates with work engagement and job satisfaction, and negatively correlates with burnout. Hierarchical regression analyses also point out that, among all the perceived emotional intelligence subdimensions, the use of emotion is the best predictor of the study variables, even when controlling for gender differences. These results suggest that emotional intelligence may have a protective role in preventing negative working experiences of teachers.
\end{abstract}

Keywords: emotional intelligence, burnout, work engagement, job satisfaction, teachers, education

\section{Introduction}

In the past years, the teaching profession has undergone several modifications due to social, cultural and political changes. Currently, in Europe, $2 / 3$ of the teaching population is composed of women, 1/3 of which is less than 40 years old (European Commission/EACEA/Eurydice, 2015). Specifically, Italian teachers reflect this composition, and their salaries are among the lowest in Europe (Cavalli \& Argentin, 2010). The Italian school system has been deeply affected by the changes in

Antonella D'Amico, Department of Psychology, Educational Science and Human Movement, University of Palermo, Viale delle Scienze, Edificio 15-90128 Palermo, Italy. E-mail:antonella.damico@unipa.it 
economic and political reforms, adding to the job new duties and responsibilities, resulting in a heavier workload. Diversity and multicultural classes, special educational needs and introduction of new technologies are only a few examples (Kyriacou, 2001; Okojie, 2011). Moreover, there is a specific education and training for Italian primary school teachers, whereas there is no adequate professional training for the secondary school teachers (Cavalli \& Argentin, 2010). Italian teachers complain about the loss of social prestige, low wages, inadequate educational equipment, parents' disinterest, students' poor learning motivation, and the lack of social support from school directors (Simbula, Panari, Guglielmi, \& Fraccaroli, 2012). Teachers' working conditions have a strong impact on their mental and physical well-being, as well as on their social and educational efficacy (Brackett, Palomera, Mojsa-Kaja, Reyes, \& Salovey, 2010). These work-related stressors can easily increase burnout risk and stress levels, which can result in low engagement and job satisfaction, ending up in absenteeism, poor performances, early retirement and professional dropout. An inadequate performance by the teachers, given their crucial role in education and social development, could have negative outcome on students' personal and academic achievements (Simbula, Mazzetti, \& Guglielmi, 2011).

\section{Emotional Intelligence}

In the last decades, researchers have shown interest in preventing burnout, searching for protective factors that can promote psychological well-being and act as buffers against burnout. For this reason, studies on emotional intelligence as an index of psychological well-being and a resource against the effects of burnout syndrome have increased in number (Mérida-López \& Extremera, 2017).

Emotional intelligence (EI) refers to a set of cognitive abilities that allow people to perceive, understand, express and manage emotional information (Mayer, Caruso, \& Salovey, 2016; Salovey \& Mayer, 1990). More specifically, it is defined as a set of emotional and cognitive abilities which involves "the ability to perceive accurately, appraise, and express emotion; the ability to access and/or generate feelings when they facilitate thought; the ability to understand emotion and emotional knowledge; and the ability to regulate emotions to promote emotional and intellectual growth" (Mayer \& Salovey, 1997, p. 10). This definition, based on the ability model of emotional intelligence, differs substantially from the trait or mixed models that conceive emotional intelligence as a set of abilities, motivational factors, and personality traits (Mayer, Caruso, \& Salovey, 1999; Mayer \& Salovey, 1997; Mayer, Salovey, \& Caruso, 2000, 2004). Different models that define EI use different ways to measure it (Petrides \& Furnham, 2000). In trait EI models, stemming from the field of personality research, self-report tools should be used to measure EI, while information processing EI or ability EI models are based on traditional intelligence studies and use performance measures (Brackett \& Mayer, 2003; Brackett, Rivers, Shiffman, Lerner, \& Salovey, 2006; Mayer, 2004; Mayer et al., 2000, 2004; Mayer, 
Salovey, Caruso, \& Sitarenios, 2003; Petrides \& Furnham, 2000; Van Roosy, Viswesvaran, \& Pluta, 2005). Self-report tools can also be divided in measures based on trait-EI models (e.g., the Emotional Quotient Inventory, Bar-On, 1997; the Emotional Competence Inventory, Boyatzis \& Sala, 2004) and in self-report measures based on the Mayer and Salovey's (1997) ability model of EI (e.g., the Emotional Self-Efficacy Scale, Kirk, Shutte, \& Hine, 2008; the Wong and Law Emotional Intelligence Scale, Wong \& Law, 2002).

Women usually obtain higher levels of emotional intelligence than men when measured both with self-report (Di Fabio \& Palazzeschi, 2008; Petrides \& Furnham, 2000; Sala, 2002) and performance measures (Mayer et al., 1999; Mayer, Salovey, $\&$ Caruso, 2002), although self-report results are not always consistent (Brackett \& Mayer, 2003; D'Amico, 2018). In addition, older people consistently present higher levels of emotional intelligence compared to younger counterparts, regardless of measurement tools that is used (Bar-On, 2006; Mayer et al., 1999, 2002; Sala, 2002).

Higher emotional intelligence is related to general psychological well-being, job satisfaction, better job performance and organizational commitment (Brackett \& Mayer, 2003; Wong \& Law, 2002). Moreover, higher emotional intelligence in teachers is related to professional self-efficacy, i.e., the ability to motivate students, to use adequate educational strategies and to manage classes (Di Fabio \& Palazzeschi, 2008; Penrose, Perry, \& Ball, 2007). Emotionally competent teachers create an educational environment which facilitates the development of self-awareness in students and increase their social, emotional and interpersonal abilities (Fried, Mansfield, \& Dobozy, 2015; Hernàndez-Amoròs \& Urrea-Solano, 2017; Roorda, Koomen, Spilt, \& Oort, 2011; Šarić, 2015).

\section{Burnout}

Burnout is defined as a prolonged response of an individual chronically exposed to emotional and interpersonal stressors on the workplace (Maslach, Schaufeli, \& Leiter, 2001). It is a multidimensional syndrome of emotional exhaustion, depersonalization and reduced personal accomplishment (Maslach \& Jackson, 1981; Maslach, Jackson, \& Leiter, 1996; Maslach et al., 2001). Compared to men, women present a higher burnout risk in some studies (Fernet, Guay, Senécal, \& Austin, 2012; Gleichgerrcht \& Decety, 2013; Kokkinos, 2006; Maslach et al., 2001; Purvanova \& Muros, 2010) and lower risk in others (Bekker, Croon, \& Bressers, 2005; Haque \& Aslam, 2011; Seibt, Spitzer, Druschke, Scheuch, \& Hinz, 2013). Age seems to have a negative correlation to burnout, decreasing the risk of experiencing it as the individual grows older (Brewer \& Shapard, 2004; Gavish \& Friedman, 2010; Maslach et al., 2001). Young workers are at higher risk of developing burnout, while older ones are more mature, can resort to their experience to face problems at work or hold high-status jobs and therefore have more resources (Brewer \& Shapard, 2004; Guglielmi \& Fraccaroli, 2016). This difference may be also due to the survival bias: 
people who experience burnout in their carrier tend to abandon their profession earlier, leaving on the job only those who present lower levels of burnout or none (Maslach et al., 2001). Several factors can play a role in increasing burnout in teachers: lack of motivation in students (Hastings \& Bham, 2003; Kokkinos, 2007; Skaalvik \& Skaalvik, 2010), excessive workload and busy schedule (Dorman, 2003; Kyriacou, 2001), frequent reforms and changes in administration, role ambiguity and role conflict (Kyriacou, 2001), poor administrative support (Akbaba, 2014; Dorman, 2003; Grayson \& Alvarez, 2008), and low social prestige and overcrowded classes (Cano-Garcia, Padilla-Munoz, \& Carrasco-Ortiz, 2005). Burnout in teachers is associated with absenteeism, intention to leave, low job satisfaction, negative attitudes and disinterest towards students and their education (Grayson \& Alvarez, 2008; Hoglund, Klingle, \& Hosa, 2015; Küçükoğlu, 2014; Skaalvik \& Skaalvik, 2010).

Emotional intelligence negatively correlates with burnout, using both selfreport measures (Alavinia \& Ahmadzadeh, 2012; Durán, Extremera, Rey, Fernández-Berrocal, \& Montalbán, 2006; Mérida-López \& Extremera, 2017; Rey, Extremera, \& Pena, 2016; Vaezi \& Fallah, 2011) and performance measures (Brackett et al., 2010). Burnout is always assessed using self-report measures, and the Maslach Burnout Inventory (MBI; Maslach \& Jackson, 1981; Maslach et al., 1996 ) is the most used measurement tool in this research field (Heinemann \& Heinemann, 2017).

\section{Work Engagement}

Work engagement is a persistent, positive and satisfying work-related mental state, characterized by vigour, dedication and absorption during work activities (Schaufeli, Salanova, Gonzales-Roma, \& Bakker, 2002). Some authors see work engagement as the direct opposite of burnout (Maslach et al., 2001), while others see the two constructs as interdependent (Schaufeli \& Bakker, 2004; Schaufeli, Bakker, \& Salanova, 2006).

Personal and work-related resources in occupational context influence work engagement and burnout levels by helping the management of work demands, resulting also in positive outcomes such as organizational citizenship behaviours, work satisfaction, commitment and overall well-being (Hakanen, Bakker, \& Schaufeli, 2006; Simbula et al., 2011, 2012). Teachers are among the professionals showing higher levels of work engagement (Schaufeli et al., 2006), with no significant differences between men and women (Balducci, Fraccaroli, \& Schaufeli, 2010; Schaufeli et al., 2006). Considering the relationship between age and work engagement, results are not consistent: on one side, the relation is weak or not significant (Balducci et al., 2010; Schaufeli et al., 2006), on the other age and work engagement are related (James, Besen, Matz-Costa, \& Pitt-Catsouphes, 2010, 2012; Kim \& Kang, 2016; Pitt-Catsouphes \& Matz-Costa, 2008). 
Only a few studies examined the correlation between emotional intelligence and work engagement in a school environment and used a self-report scale based on the ability model to measure EI: the Wong and Law Emotional Intelligence Scale (Wong $\&$ Law, 2002). These studies show that EI is strongly correlated with all three work engagement dimensions (Mérida-López, Extremera, \& Rey, 2017; Pena, Rey, \& Extremera, 2012). These results specifically show a correlation between perceived emotional intelligence and work engagement due to the use of self-report ability EI. Like burnout, work engagement is also assessed using only self-report measures, such as the Utrecht Work Engagement Scale (UWES; Schaufeli et al., 2006).

\section{Job Satisfaction}

Job satisfaction is defined as a positive attitude resulting from worker's appraisal of job experience (Locke, 1976). Job satisfaction antecedents can be divided into two categories: work-related factors, and individual factors such as personality traits and previous work experiences (Spector, 1997). Due to a general disagreement among the scholars, there is no unanimous consent about the working characteristics that affect job satisfaction (Astrauskaite, Vaitkevičius, \& Perminas, 2011).

Various work features may be differently related to job satisfaction: task and development, communication and organization, climate, contract, image, context, evaluation and workload (Cortese, 2004). Moreover, job satisfaction is associated with a better work performance (Schleicher, Watt, \& Greguras, 2004), low absenteeism (Tharenou, 1993), low turnover and organizational citizenship behaviours (Spector, 1997), better psychological and physical health (Avallone \& Paplomatas, 2005), and life satisfaction (Judge \& Watanabe, 1994).

Results about gender differences are not unanimous: if some studies showed that women report higher levels of job satisfaction compared to men (Jyoti \& Sharma, 2006; Murray \& Atkinson, 1981) others showed the opposite (Forgionne \& Peeters, 1982; Weaver, 1974), whereas others found no differences (Eskildsen, Kristensen, \& Westlund, 2003; Franěk \& Večeřa, 2008). The relationship between age and job satisfaction is not always consistent: on one side, job satisfaction decreases over time (Franěk \& Večeřa, 2008), on the other, it increases as time passes (Eskildsen et al., 2003; Rhodes, 1983; Riza, Ganzach, \& Liu, 2016). With regards to the relationship between emotional intelligence and job satisfaction, studies showed a significant positive correlation (Akomolafe \& Ogunmakin, 2014; Platsidou, 2010; Yin, Lee, Zhang, \& Jin, 2013).

Quantitative self-report measurements are usually used to assess job satisfaction levels. These tools are classified in two different categories: those that measure the general satisfaction (e.g., Job in General Scale; Ironson, Smith, Brannick, Gibson, $\&$ Paul, 1989) and those that measure the job satisfaction (e.g., the Job Satisfaction Survey; Spector, 1985). The holistic approach asserts the possibility to measure job 
satisfaction through single-item tools. Conversely, the elementary approach aims to assess every single work features (Argentero, Cortese, \& Piccardo, 2008; Spector, 1997). In the Italian context, Cortese (2001) developed an organizational satisfaction scale (Italian Questionario di Soddisfazione Organizzativa - QSO), which could be included in the elementary approach measurement. Every item, indeed, represents the score of each work-related factors investigated.

\section{Aims and Hypotheses}

This research aims to study the relationship between perceived emotional intelligence and the three psychological and professional well-being indexes: burnout, work engagement and job satisfaction. A negative correlation with burnout and a positive correlation with work engagement and job satisfaction is expected to be found in our group of Italian teachers.

This work is exploratory because to the best of our knowledge there are no such studies regarding Italian teachers.

\section{Method}

\section{Participants}

The study sample was composed of 238 Italian teachers. The majority were recruited in three different schools in Palermo, while the rest of the sample was composed of teachers who voluntarily participated in the research through an online platform. There were 207 women and 31 men in the sample: the predominance of women reflects the real composition of the Italian teaching profession (Cavalli \& Argentin, 2010; European Commission/EACEA/Eurydice, 2015). The mean age was 50 years, ranged from 26 to $66(S D=9.16)$. The participants worked in different school levels: the $6.8 \%$ of them were infantry school teachers, $21.6 \%$ were primary school teachers, the $71.7 \%$ were secondary school teachers. Their professional experience ranged from 1 to 42 years $(M=20.97 ; S D=10.92)$. Most of the teachers in the sample taught humanities $(48.3 \%)$, followed by those of the scientific $(21 \%)$ and technical (19\%) subjects. Teachers for students with special needs represented $10 \%$ of the sample. The mean class size was composed of 21.17 pupils, ranging from a minimum of 13 to a maximum of $30(S D=3.12)$.

\section{Materials and Procedure}

The three recruited schools were informed about the research and asked to participate. The participants were given a brief introduction to the project and full information about the basis of their participation: their anonymity was guaranteed. The administration occurred at school before or after the teachers' board meeting. 
The research protocol included a demographics data sheet, the Wong and Law Emotional Intelligence Scale (WLEIS; Wong \& Law, 2002), the Copenhagen Burnout Inventory (CBI; Kristensen et al., 2005), the Utrecht Work Engagement Scale (UWES; Schaufeli et al., 2006), the Organizational Satisfaction Scale (Questionario di Soddisfazione Organizzativa, QSO; Cortese, 2001).

Wong and Law Emotional Intelligence Scale. This scale is built considering the Davies, Stankov, and Roberts (1998) emotional intelligence definition. This definition effectively sums up previous emotional intelligence research literature and it is almost close to the one conceived by Mayer and Salovey (1997). A self-report measure as the WLEIS was used, even though the ability-model EI should be measured using performance tools, such as the MSCEIT (Mayer et al., 2002). This choice was made due to practical needs of administration and scoring, considering that there are significant differences between ability self-report and mixed self-report measures (Fernàndez-Berrocal \& Extremera, 2016; Mérida-López \& Extremera, 2017). WLEIS consists of 16 items, which are scored on a 7-point Likert-type scale $(1=$ totally disagree to $7=$ totally agree $)$ which aim to assess people's perception about their own emotional abilities: the Perceived Emotional Intelligence - PEI. The content of the items relates to four EI dimensions: Self-Emotion Appraisal (SEA), Others' Emotion Appraisal (OEA), Use of Emotion (UOE) and Regulation of Emotion (ROE). The scale has shown good psychometric properties, adequate internal consistency and evidence of validity (Law, Wong, \& Song, 2004). Furthermore, the scale was weakly related to personality dimensions measured by the Big Five Questionnaire (Law et al., 2004). WLEIS has been translated into several languages, including Italian, maintaining the same factorial structure in each different cultural context (Iliceto \& Fino, 2017). The internal consistency of the scale was verified for the sample of the present study: in line with earlier studies, it was found a significant internal consistency $(\alpha=.94)$.

Copenhagen Burnout Inventory. The CBI is based on the fundamental idea that exhaustion and fatigue are central components of the burnout syndrome. The aim of the scale, therefore, is assessing physical and mental states in specific domains and life contexts, including the work domain and specifically the school context. The scale consists of 19 items scored on a 5-point type scale $(1=$ never to $5=$ always $)$. The items of the CBI are grouped into three sub-scales that reflect the underlying dimensions of burnout syndrome: Personal Burnout (PB), Work-Related Burnout (WB), and Student-Related Burnout (SB). The scale maintained good psychometric properties when applied in different cultural context (Platsidou \& Daniilidou, 2016). Thus, in the present study, the Italian version of the CBI was administered to the participants (Fiorilli et al., 2015). Once again, Cronbach's alpha coefficient showed good levels of internal consistency $(\alpha=.93)$.

Utrecht Work Engagement Scale. The short 9-items Italian version of the UWES was used in the research (Balducci et al., 2010). The scale is composed of three 
underlined dimensions of work engagement: Vigour (VI), Dedication (DE) and Absorption (AB). The 9 items are scored on a 7-point scale, from 0 (never) to 6 (always). In line with the results of Balducci et al. (2010), a good reliability of the scale was found $(\alpha=.93)$.

Organizational Satisfaction Scale (QSO; Cortese, 2001). The scale was made for assessing the employees' job satisfaction in different Italian organizational contexts. The QSO is composed of 20 items, each of which measures satisfaction with different features of the work environment. Hence, from QSO is possible to obtain separate scores for each dimension and a total score (ISO - Organizational Satisfaction Index) which derives from the sum of all the items scores. The items are scored on a 7-point Likert type scale, from (1) not at all satisfied to (7) completely satisfied. The Cronbach's alpha coefficient exceeded the value of .70, resulting to be satisfactory (.93) in this case as well. Although using a scale calibrated on a business context may be a research limit, to the best of our knowledge no satisfaction measures have been created for the Italian school context yet.

\section{Results}

\section{Descriptive Analyses}

Data analyses were conducted using the SPSS Statistics software. Descriptive analyses are shown in Table 1.

Table 1

Descriptive Statistics for All the Scales

\begin{tabular}{llllllllr}
\hline \multirow{2}{*}{ WLEIS } & & Min & Max & $M$ & $S D$ & $C V$ & Skewness & Kurtosis \\
& & 1 & 7 & 5.35 & 0.89 & 16.64 & -0.98 & 2.30 \\
& SEA & 1 & 7 & 5.46 & 1.06 & 19.41 & -0.76 & 1.04 \\
& OEA & 1 & 7 & 5.45 & 0.97 & 17.80 & -0.83 & 1.65 \\
& UOE & 1 & 7 & 5.51 & 1.06 & 19.24 & -1.03 & 1.48 \\
& ROE & 1 & 7 & 5.00 & 1.16 & 23.25 & -0.58 & -0.04 \\
\hline \multirow{6}{*}{ UWES } & & 0 & 6 & 4.94 & 0.95 & 19.23 & -1.47 & 3.16 \\
& VI & 0 & 6 & 4.81 & 1.06 & 22.04 & -1.46 & 3.25 \\
& DE & 0 & 6 & 5.07 & 1.05 & 20.71 & -1.50 & 2.84 \\
& AB & 0 & 6 & 4.93 & 1.02 & 20.69 & -1.35 & 2.20 \\
\hline
\end{tabular}


D’Amico, A., Geraci, A., Tarantino, C.:

Perceived Emotional Intelligence and Teacher's Professional Well-Being

\begin{tabular}{lcccccccc}
\hline & & Min & Max & $M$ & $S D$ & $C V$ & Skewness & Kurtosis \\
\hline ISO & & 0 & 140 & 86.58 & 20.86 & 24.09 & -0.37 & 0.80 \\
& GN & 0 & 98 & 63.90 & 15.74 & 24.63 & -0.48 & 0.70 \\
& CT & 0 & 28 & 14.44 & 4.51 & 31.23 & 0.06 & 0.09 \\
& CN & 0 & 14 & 8.24 & 2.92 & 35.44 & -0.34 & -0.50 \\
\hline \multirow{2}{*}{ CBI } & & 2.63 & 76.32 & 34.23 & 16.32 & 47.68 & 0.30 & -0.43 \\
& PB & 0 & 91.67 & 40.83 & 19.02 & 46.58 & 0.10 & -0.43 \\
& WB & 0 & 82.14 & 33.37 & 16.83 & 50.43 & 0.29 & -0.41 \\
& SB & 0 & 79.17 & 28.64 & 17.83 & 62.26 & 0.45 & -0.41 \\
\hline
\end{tabular}

Note. WLEIS $=$ Emotional Intelligence; SEA $=$ Self-Emotion Appraisal; OEA $=$ Others' Emotion Appraisal; UOE = Use of Emotion; ROE = Regulation of Emotion; UWES = Work Engagement; VI = Vigour; $\mathrm{DE}=$ Dedication; $\mathrm{AB}=$ Absorption; $\mathrm{ISO}=$ Organizational Satisfaction Index; $\mathrm{GN}=$ General Satisfaction; $\mathrm{CT}=$ Satisfaction with the Contract; $\mathrm{CN}=$ Satisfaction with the Context; $\mathrm{CBI}=$ Burnout; $\mathrm{PB}=$ Personal Burnout; $\mathrm{WB}=$ Work-Related Burnout; $\mathrm{SB}=$ Student-Related Burnout.

The mean level of the Perceived emotional intelligence (PEI) in the sample is high $(M=5.35 ; S D=0.89)$, as well as the mean level of each of the PEI subdimensions: in particular, teachers report higher scores in the Use of Emotion $(M$ $=5.51 ; S D=1.06)$. Work engagement mean score is also high $(M=4.94 ; S D=0.95)$ with Dedication $(M=5.07 ; S D=1.05)$ having the highest score. The mean level of job satisfaction is relatively high (ISO: $M=86.58 ; S D=20.86$ ) as well as the mean level of its subdimensions. Regarding burnout, the mean score is low $(M=34.23 ; S D$ $=16.32$ ) especially for Student-Related Burnout for which teachers report the lowest scores $(M=28.64 ; S D=17.83)$.

Skewness measure for the Perceived emotional intelligence (PEI) has a negative value -0.98 , indicating a greater presence of values in the highest part of the distribution, which means most of the participants agree on possessing emotional abilities. Work engagement and job satisfaction have also the same negative skewness scores. On the contrary, skewness value for burnout results positive (.30), showing that most of the answers are located in the left part of the distribution, where the values are lower, meaning that participants rarely experience burnout symptoms.

Kurtosis scores for all work engagement scales is above zero (UWES: 3.16 ; VI: 3.25; DE: 2.84; AB: 2.20), showing a concentration of values around the mean score. As for PEI, values are greater than 0 except for ROE scale where concentration is normal around the mean (-.04). Burnout and job satisfaction scales also report values both slightly less and greater than zero.

Variation coefficient shows a greater variability in $\mathrm{CBI}$ scale $(C V=47.68)$ than WLEIS ( $C V=16.63)$, UWES ( $C V=19.23)$, and QSO (ISO: $C V=24.09)$. Looking at the subscales, ROE has the highest variability within WLEIS $(C V=23.25)$, VI for UWES $(C V=22.04), \mathrm{CN}$ for QSO $(C V=35.44)$, and $\mathrm{SB}$ for $\mathrm{CBI}(C V=62.26)$. 


\section{Gender Differences}

Statistics for gender differences analyses are presented in Table 2.

Table 2

Gender Differences in the Levels of Perceived Emotional Intelligence, Work Engagement, Job Satisfaction and Burnout

\begin{tabular}{lccccccc}
\hline & & \multicolumn{2}{c}{ Males } & \multicolumn{2}{c}{ Females } & \multicolumn{2}{c}{$t$-test } \\
\cline { 3 - 8 } & & $M$ & \multicolumn{1}{c}{$S D$} & $M$ & \multicolumn{1}{c}{$S D$} & $t$ & $d f$ \\
\hline \multirow{6}{*}{ WLEIS } & & 5.09 & 0.89 & 5.39 & 0.89 & -1.80 & 236 \\
& SEA & 5.23 & 1.17 & 5.50 & 1.04 & -1.34 & 236 \\
& OEA & 5.11 & 0.98 & 5.50 & 0.96 & $-2.06^{*}$ & 236 \\
& UOE & 5.05 & 1.08 & 5.58 & 1.04 & $-2.65^{* *}$ & 236 \\
& ROE & 4.95 & 0.94 & 5.00 & 1.19 & -0.20 & 236 \\
\hline UWES & & 4.46 & 1.02 & 5.01 & 0.92 & $-3.08^{* * *}$ & 235 \\
& VI & 4.33 & 1.07 & 4.88 & 1.04 & $-2.70^{* *}$ & 235 \\
& DE & 4.45 & 1.24 & 5.17 & 0.99 & $-3.63^{* * *}$ & 235 \\
& AB & 4.58 & 1.04 & 4.99 & 1.01 & $-2.08^{*}$ & 235 \\
ISO & & 83.77 & 18.02 & 87.00 & 21.26 & -0.80 & 236 \\
& GN & 62.10 & 13.31 & 64.16 & 16.08 & -0.68 & 236 \\
& CT & 13.68 & 4.00 & 14.56 & 4.58 & -1.01 & 236 \\
& CN & 8.00 & 2.61 & 8.28 & 2.97 & -0.50 & 236 \\
\hline CBI & & 35.19 & 15.26 & 34.10 & 16.50 & 0.35 & 236 \\
& PB & 39.38 & 16.83 & 41.06 & 19.35 & -0.46 & 236 \\
& WB & 34.91 & 16.74 & 33.14 & 16.87 & 0.54 & 236 \\
& SB & 31.32 & 15.59 & 28.24 & 18.14 & 0.90 & 236 \\
\hline
\end{tabular}

Note. WLEIS $=$ Emotional Intelligence; SEA $=$ Self-Emotion Appraisal; OEA $=$ Others' Emotion Appraisal; UOE = Use of Emotion; ROE = Regulation of Emotion; UWES = Work Engagement; VI = Vigour; $\mathrm{DE}=$ Dedication; $\mathrm{AB}=$ Absorption; ISO = Organizational Satisfaction Index; $\mathrm{GN}=$ General Satisfaction; $\mathrm{CT}=$ Satisfaction with the Contract; $\mathrm{CN}=$ Satisfaction with the Context; $\mathrm{CBI}=$ Burnout; $\mathrm{PB}=$ Personal Burnout; $\mathrm{WB}=$ Work-Related Burnout; $\mathrm{SB}=$ Student-Related Burnout; ${ }^{*} p<.05 ;{ }^{* *} p<.01$; ${ }^{* * *} p<.001$.

Women report higher mean scores than men in Others' Emotion Appraisal $(t(1,236)=-2.06, p<.05)$, Use of Emotion $(t(1,236)=-2.65, p<.01)$, work engagement $(t(1,235)=-3.08, p<.001)$, Vigour $(t(1,235)=-2.70, p<.01)$, Dedication $(t(1,235)=-3.63, p<.001)$, and Absorption $(t(1,235)=-2.08, p<.05)$. Women also report higher mean scores than men in job satisfaction dimensions, 
whereas men report higher mean scores than women in Work-Related Burnout and Student-Related Burnout, but these differences are not statistically significant.

\section{Correlation Analyses}

In order to test correlation hypotheses, Pearson linear product-moment correlation coefficient among variables was computed, with the assumption of using a Likert scale as an interval scale. Results are presented in Table 3.

There are no significant correlations among age, years of work experience, and study variables, therefore the $r$-values are not included in Table 3. On the contrary, all the correlations among study variables are significant: focusing only on total scores, PEI is highly and positively correlated with total scores of work engagement $(r=.42, p<.01)$, job satisfaction $(r=.38, p<.01)$, whereas it is negatively correlated with total score of burnout $(r=-.31, p<.01)$. The total score of PEI presents also high correlation with some dimensions of work engagement (Vigour: $r=.41, p<.01$; Dedication: $r=.40, p<.01$ ), and job satisfaction (General Satisfaction: $r=.39, p$ $<.01)$. Concerning the PEI subscales, the Use of Emotion dimension presents the highest positive correlation with all the three work engagement dimensions (VI: $r$ $=.44, p<.01$; DE: $r=.45, p<.01 ; \mathrm{AB}: r=.38, p<.01)$, with General Satisfaction $(r=.36, p<.01)$, and a negative correlation with Work-Related Burnout $(r=-.34, p$ $<.01)$.

\section{Regression Analyses}

Four hierarchical regression analyses were conducted in order to further examine the relationship between the variables (Table 4). Since we have found significant gender differences in some of the study variables, in each analysis the variable gender was entered as a covariate in the model at the first step, for controlling its effect (Durán et al., 2006); then, the four dimensions of PEI were included. Age and years of work experience were not included as covariate since they were not correlated with criterion variables. Three regression analyses were conducted separately for overall scores of work engagement, job satisfaction and burnout, entered in each model as dependent variables.

Results demonstrated that all the three dependent variables considered are significantly predicted by the PEI subdimensions, even when the gender variable is controlled for (Work Engagement: $\Delta R^{2}=.21, p<.001$; Burnout: $\Delta R^{2}=.15, p<.001$; Job Satisfaction: $\Delta R^{2}=.11, p<.001$ ).

Among the PEI subdimensions, the Use of Emotion has resulted to be the only significant one in predicting the variations for all the study variables: work engagement $(\beta=.39, p<.001)$, burnout $(\beta=-.26, p<.01)$ and job satisfaction $(\beta$ $=.19, p<.05)$. Moreover, the Others' Emotion Appraisal predicts variations only for work engagement $(\beta=.19, p<.05)$. 


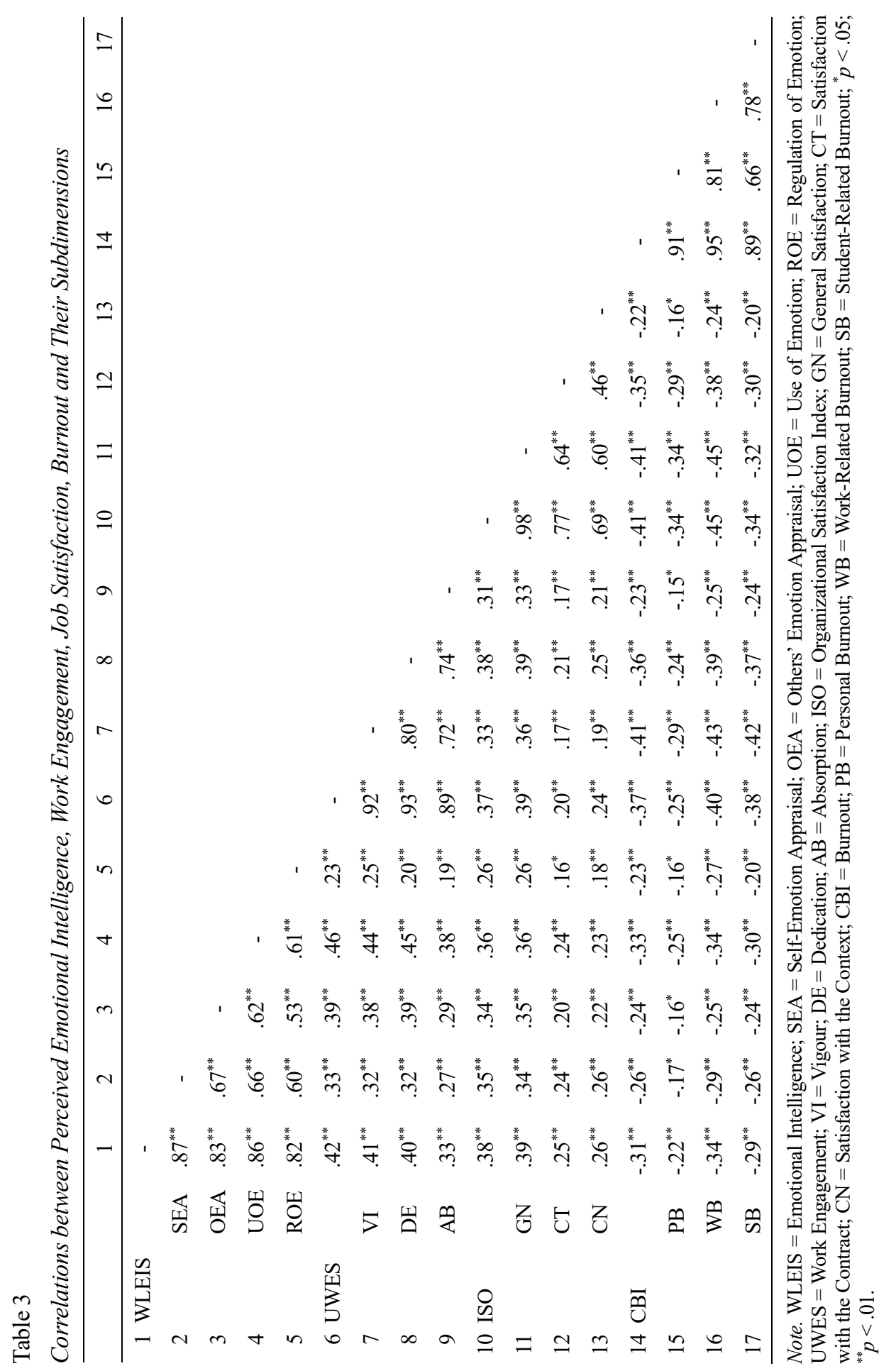


Table 4

Hierarchical Regression Analyses: Work Engagement, Job Satisfaction and Burnout as Criterion Variables

\begin{tabular}{|c|c|c|c|c|c|c|c|c|c|c|c|c|}
\hline \multirow{2}{*}{ Predictors } & \multicolumn{4}{|c|}{ Work Engagement } & \multicolumn{4}{|c|}{ Job Satisfaction } & \multicolumn{4}{|c|}{ Burnout } \\
\hline & $R^{2}$ & $F$ & $\beta$ & $\Delta R^{2}$ & $R^{2}$ & $F$ & $\beta$ & $\Delta R^{2}$ & $R^{2}$ & $F$ & $\beta$ & $\Delta R^{2}$ \\
\hline Step 1 & .04 & 9.48 & & .04 & .00 & .64 & & .00 & .00 & .12 & & .00 \\
\hline Gender & \multicolumn{4}{|c|}{$-.20^{* *}$} & \multicolumn{4}{|c|}{-.05} & \multicolumn{4}{|c|}{.02} \\
\hline Step 2 & .25 & 15.39 & & $.21^{* * *}$ & .16 & 8.52 & & $.15^{* * *}$ & .11 & 5.79 & & $.11^{* * *}$ \\
\hline SEA & & & .01 & & & & .14 & & & & -.05 & \\
\hline OEA & & & $.19^{*}$ & & & & .13 & & & & -.03 & \\
\hline UOE & & & $.39^{* * *}$ & & & & $.19^{*}$ & & & & $-.26^{* *}$ & \\
\hline ROE & & & -.11 & & & & -.01 & & & & -.02 & \\
\hline
\end{tabular}

Note. SEA = Self-Emotion Appraisal; OEA = Others' Emotion Appraisal; UOE = Use of Emotion; ROE $=$ Regulation of Emotion; ${ }^{*} p<.05 ;{ }^{* *} p<.01 ;{ }^{* * *} p<.001$.

\section{Discussion}

The research aimed to assess if teachers who perceive themselves as emotionally competent experience high levels of work engagement and job satisfaction, and low levels of burnout. Descriptive analyses revealed that teachers in the sample report high mean scores for perceived emotional intelligence, work engagement and job satisfaction, whereas burnout levels are low. These results support those studies that show how teachers are enthusiastic, engaged and satisfied about their work even if they are facing many stressors (Hakanen et al., 2006; Simbula et al., 2012).

Gender seems to have an influence: women perceived themselves more emotionally competent than men in the ability to evaluate others' emotions and in the ability to use emotions. They also tend to experience higher levels of work engagement compared to men. These results support those studies that report high levels of work engagement (Balducci et al., 2010; Schaufeli et al., 2006) and emotional intelligence in women (Di Fabio \& Palazzeschi, 2008; Petrides \& Furnham, 2000; Sala, 2002). No significant gender differences were found for job satisfaction and this is consistent with previous studies (Eskildsen et al., 2003; Franěk $\&$ Večeřa, 2008). Also, no significant differences were found in the levels of burnout between men and women but this results, as already mentioned, contrast with general research that shows not consistent and often opposite differences between males and females in their experience of burnout (Bekker et al., 2005; Fernet et al., 2012; Gleichgerrcht \& Decety, 2013; Haque \& Aslam, 2011; Kokkinos, 2006; Maslach et al., 2001; Purvanova \& Muros, 2010). 
None of the study variables is correlated with age and these results are consistent with those studies which failed to find a relationship between age and work engagement (Balducci et al., 2010; Schaufeli et al., 2006), whereas they are in contrast with previous studies that showed a significant relation between age and emotional intelligence (Bar-On, 2006; Sala, 2002), burnout (Brewer \& Shapard, 2004; Gavish \& Friedman, 2010; Maslach et al., 2001), and job satisfaction (Eskildsen et al., 2003; Franěk \& Večeřa, 2008; Riza et al., 2016). Our results, however, may be influenced by the range of age of our sample, which is relatively narrow, with a predominance of over 50 years old teachers.

Correlation analyses confirm our main research hypotheses: there is a positive correlation between PEI and work engagement, and between PEI and job satisfaction. The positive correlation between PEI and work engagement is consistent with previous studies by Mérida-López et al. (2017) and Pena et al. (2012). The positive correlation between PEI and job satisfaction supports previous studies by Akomolafe and Ogunmakin (2014), Platsidou (2010), and Yin et al. (2013). The negative correlation between the PEI and burnout and their subdimensions are also consistent with other international findings by Brackett et al. (2010), Durán et al. (2006), Mérida-López and Extremera (2017), and Rey et al. (2016).

Further results of this study show that Use of Emotion, among PEI dimensions, is the best predictor of variations in work engagement, job satisfaction and burnout. In addition, Others' Emotion Appraisal predicts variations in work engagement. Teachers in our sample, who perceive themselves as competent in appraising emotions and using them in positive and adaptive ways, declare to feel more engaged at work, more satisfied, and to experience fewer burnout symptoms. These results are very interesting since they might suggest, as claimed by D'Amico (2018), that the use of emotion represents the higher level of emotional intelligence and emotion regulation abilities. Moreover, the items used by Wong and Low (2002) in the Use of emotion subscale, refer to self-regulation strategies of self-motivation, selfengagement and goal setting (i.e. I always set goals for myself and then try my best to achieve them or I would always encourage myself to try my best).

\section{Conclusion}

This research represents the first attempt to examine the actual state of teachers within the Italian school context. The results demonstrate that, as already found in the examined international literature, Italian teachers who perceive themselves as emotionally competent also experience higher levels of work engagement and job satisfaction, and lower levels of burnout. There is still more research to be done on the nature and the cause-effect direction of these relations, however, we can affirm that emotions play a central role for teachers' psychological well-being in school context. Emotional abilities could provide crucial resources in an occupational 
context with an increasing burnout risk (Alavinia \& Ahmadzadeh, 2012; Brackett et al., 2010; Mérida-López \& Extremera, 2017; Rey et al., 2016; Vaezi \& Fallah, 2011), and this depends on its incessantly growing work demands.

Moreover, this research presents some limits most of which depend on methodological choices. The lack of randomization may have determined some distortions in the sample composition and consequently on the results. Though the sample seems to reflect the composition of Italian teachers, these results cannot be generalized to the entire teacher population.

The exclusive use of self-report measures for all the study variables, especially for emotional intelligence, is another limit. Even though their use is very common in psychological research due to administration and scoring logistics, these tools are susceptible to falsification or self-presentation bias (Day \& Carroll, 2008). This is particularly true for emotional intelligence construct: one's self-perception is not always accurate, and the belief of owning certain abilities does not always imply their adequate or effective use (Brackett \& Mayer, 2003; Brackett et al., 2006). In future studies, a performance measure of EI should be included, in order to offer a more accurate view on emotional and meta-emotional abilities in teachers. Moreover, the use of the Organizational Satisfaction Scale $(Q S O)$ as a tool for measuring job satisfaction in school context may be another limit: even though QSO has good psychometric properties, it was conceived for a corporate context, and a more specific school-oriented tool should be used in future studies.

Present and future results could set the foundation for promoting and implementing emotional intelligence-based programs in the Italian school system and in teachers' training and education.

Despite these limitations, our results encourage us to consider emotional intelligence as a key competence to develop in teachers' training and education. Emotionally intelligent teachers could live a more positive and valuable professional experience. Consequently, they could establish a positive emotional climate in the class, which is essential for students' social development and academic achievements (Roorda et al., 2011) particularly in the case of students with learnig disordes (D'Amico \& Guastafetrro, 2017).

We are convinced that, in order to empower emotional intelligence in teachers, it is not enough to teach them how to apply Social Emotional Learning methods with their students. On the contrary, it is crucial to provide teachers with experiential training, helping them to think about their own emotional abilities and giving them strategies and tools in order to develop emotional intelligence skills. 


\section{References}

Akbaba, S. (2014). A comparison of the burnout levels of teachers with different occupational satisfaction sources. Educational Sciences: Theory \& Practice, 14(5), 1253-1261.

Akomolafe, M. J., \& Ogunmakin, A. O. (2014). Job satisfaction among secondary school teachers: Emotional intelligence, occupational stress and self-efficacy as predictors. Journal of Educational and Social Research, 4(3), 487-498.

Alavinia, T., \& Ahmadzadeh, T. (2012). Toward a reappraisal of the bonds between emotional intelligence and burnout. English Language Teaching, 5(4), 37-50.

Argentero, P., Cortese, C. G., \& Piccardo, C. (2008). Psicologia del lavoro [Work psychology]. Milano: Raffaello Cortina.

Astrauskaite, M., Vaitkevičius, R., \& Perminas, A. (2011). Job satisfaction survey: A confirmatory factor analysis based on secondary school teacher's sample. International Journal of Business and Management, 6(5), 41-50.

Avallone, F., \& Paplomatas, A. (2005). Salute organizzativa [Organizational health]. Milano: Raffaello Cortina.

Balducci, C., Fraccaroli, F., \& Schaufeli, W. B. (2010). Psychometric properties of the Italian version of the Utrecht Work Engagement Scale (UWES-9): A cross-cultural analysis. European Journal of Psychological Assessment, 26(2), 143-149.

Bar-On, R. (1997). The bar-on emotional quotient inventory (EQ-i): A test of emotional intelligence. Toronto: Multi-Health Systems.

Bar-On, R. (2006). The Bar-on model of emotional-social intelligence (ESI). Psicothema, 18, $13-25$.

Bekker, M. H. J., Croon, M. A., \& Bressers, B. (2005). Childcare involvement, job characteristics, gender and work attitudes as predictors of emotional exhaustion and sickness absence. Work \& Stress, 19(3), 221-237.

Boyatzis, R. E., \& Sala, F. (2004). The emotional competence inventory (ECI). In G. Geher (Ed.), Measuring emotional intelligence: Common ground and controversy (pp. 147180). Hauppauge, NY: Nova Science Publishers.

Brackett, M. A., \& Mayer, J. D. (2003). Convergent, discriminant, and incremental validity of competing measures of emotional intelligence. Personality and Social Psychology Bulletin, 29(9), 1147-1158.

Brackett, M. A., Palomera, R., Mojsa-Kaja, J., Reyes, M. R., \& Salovey, P. (2010). Emotionalregulation ability, burnout, and job satisfaction among British secondary-school teachers. Psychology in the Schools, 47, 406-417.

Brackett, M. A., Rivers, S. E., Shiffman, S., Lerner, N., \& Salovey, P. (2006). Relating emotional abilities to social functioning: A comparison of self-report and performance measures of emotional intelligence. Journal of Personality and Social Psychology, 91, 780-795. 
Brewer, E. W., \& Shapard, L. (2004). Employee burnout: A meta-analysis of the relationship between age or years of experience. Human Resource Development Review, 3(2), 102123.

Cano-Garcia, F. J., Padilla-Munoz, E. M., \& Carrasco-Ortiz, M. A. (2005). Personality and contextual variables in teacher burnout. Personality and Individual Differences, 38, 929940 .

Cavalli, A., \& Argentin, G. (2010). Gli insegnanti italiani: Come cambia il modo di fare scuola. Terza indagine dell'istituto IARD sulle condizioni di vita e di lavoro nella scuola italiana [Italian teachers: How the way of school changes. Third survey by the IARD institute on living and working conditions in the Italian school.]. Bologna: Il Mulino.

Cortese, C. G. (2001). Prima standardizzazione del Questionario di Soddisfazione Organizzativa (QSO) [First standardization of the Organizational Satisfaction Questionnaire (QSO)]. Rivista di Psicologia del Lavoro e dell'Organizzazione, 8(3-4), 331-349.

Cortese, C. G. (2004). La soddisfazione per il lavoro [Job satisfaction]. Sviluppo \& Organizzazione, 206, 89-104.

D’Amico, A. (2018). Intelligenza emotiva e metaemotiva [Emotional and meta-emotional intelligence]. Bologna: Il Mulino.

D'Amico, A., \& Guastaferro, T. (2017). Emotional and meta-emotional intelligence as predictors of adjustment problems in students with Specific Learning Disorders. International Journal of Emotional Education, 9, 17-30, ISSN: 2073-7629.

Davies, M., Stankov, L., \& Roberts, R. D. (1998). Emotional intelligence: In search of an elusive construct. Journal of Personality and Social Psychology, 75(4), 989-1015.

Day, A. L., \& Carroll, S. A. (2008). Faking emotional intelligence (EI): Comparing response distortion on ability and trait-based EI measures. Journal of Organizational Behavior, 29, 761-784.

Di Fabio, A., \& Palazzeschi, L. (2008). Emotional intelligence and self-efficacy in a sample of Italian high school teacher. Social Behavior and Personality: An International Journal, 36(3), 315-326.

Dorman, J. (2003). Relationship between school and classroom environment and teacher burnout: A LISREL analysis. Social Psychology of Education, 6, 107-127.

Durán, A., Extremera, N., Rey, L., Fernández-Berrocal, P., \& Montalbán, F. M. (2006). Predicting academic burnout and engagement in educational settings: Assessing the incremental validity of perceived emotional intelligence beyond perceived stress and general self- efficacy. Psicothema, 18, 158-164.

Eskildsen, J. K., Kristensen, K., \& Westlund, A. H. (2003). Work motivation and job satisfaction in the Nordic countries. Employee Relations, 26(2), 122-136.

European Commission/EACEA/Eurydice. (2015). The teaching profession in Europe: Practice, perceptions, and policies. Eurydice report. Luxembourg: Publications Office of the European Union. 
Fernet, C., Guay, F., Senécal, C., \& Austin, F. (2012). Predicting intraindividual changes in teacher burnout: The role of perceived school environment and motivational factors. Teaching and Teacher Education, 28, 514-525.

Fernández-Berrocal, P., \& Extremera, N. (2016). Ability emotional intelligence, depression and well-being. Emotion Review, 8(4), 311-315.

Fiorilli, C., De Stasio, S., Benevene, P., Iezzi, D. F., Pepe, A., \& Albanese, O. (2015). Copenhagen Burnout Inventory (CBI): A validation study in an Italian teacher group. Testing, Psychometrics, Methodology in Applied Psychology, 22(4), 537-551.

Forgionne, G. A., \& Peeters, V. E. (1982). Differences in job motivation and satisfaction among female and male managers. Human Relations, 35(2), 101-118.

Franěk, M., \& Večeřa, J. (2008). Personal characteristics and job satisfaction. Ekonomika a Management, 4, 63-76.

Fried, L., Mansfield, C., \& Dobozy, E. (2015). Teacher emotion research: Introducing a conceptual model to guide future research. Issues in Educational Research, 25(4), $415-$ 441.

Gavish, B., \& Friedman, I. A. (2010). Novice teacher's experience of teaching: A dynamic aspect of burnout. Social Psychology of Education, 13, 141-167.

Gleichgerrcht, E., \& Decety, J. (2013). Empathy in clinical practice: How individual dispositions, gender, and experience moderate emphatic concern, burnout, and emotional distress in physicians. PLOS One, 8(4), 1-12.

Grayson, J. L., \& Alvarez, H. K. (2008). School climate factors relating to teacher burnout: A mediator model. Teaching and Teacher Education, 24, 1349-1363.

Guglielmi, D., \& Fraccaroli, F. (2016). Stress a scuola: 12 interventi per insegnanti e dirigenti [Stress at school: 12 interventions for teachers and managers]. Bologna: Il Mulino.

Hakanen, J. J., Bakker, A. B., \& Schaufeli, W. B. (2006). Burnout and work engagement among teachers. Journal of School Psychology, 43, 495-513.

Haque, A., \& Aslam, M. S. (2011). The influence of demographics on job burnout. Far East Journal of Psychology and Business, 4(2), 57-72.

Hastings, R., \& Bham, M. (2003). The relationship between student behavior patterns and teacher burnout. School Psychology International, 24(1), 115-127.

Heinemann, L. V., \& Heinemann, T. (2017). Burnout research: Emergence and scientific investigation of a contested diagnosis. SAGE Open, 1-12.

Hernández-Amorós, M. J., \& Urrea-Solano, M. E. (2017). Working with emotions in the classroom: Future teachers' attitudes and education. Procedia - Social and Behavioral Sciences, 237, 511-519.

Hoglund, W. L. G., Klingle, K. E., \& Hosan, N. E. (2015). Classroom risks and resource: Teacher burnout, classroom quality and children's adjustment in high needs elementary schools. Journal of School Psychology, 53(5), 337-357. 
Iliceto, P., \& Fino, E. (2017). The Italian version of the Wong-Law Emotional Intelligence Scale (WLEIS-i): A second-order factor analysis. Personality and Individual Differences, 116, 274-280.

Ironson, G. H., Smith, P. C., Brannick, M. T., Gibson, W. M., \& Paul, K. B. (1989). Construction of a Job in General Scale: A comparison of global, composite, and specific measures. Journal of Applied Psychology, 74(2), 193-200.

James, J. B., Besen, E., Matz-Costa, C., \& Pitt-Catsouphes, M. (2010). The end of retirement as we know it? Chestnut Hill, MA: Sloan Center on Aging \& Work at Boston College.

James, J. B., Besen, E., Matz-Costa, C., \& Pitt-Catsouphes, M. (2012). Just do it? Maybe not! Insights on activity in later life from the life \& times in an aging society study. Chestnut Hill, MA: Sloan Center on Aging \& Work at Boston College.

Judge, T. A., \& Watanabe, S. (1994). Individual differences in the nature of the relationship between job and life satisfaction. Journal of Occupational and Organizational Psychology, 67, 101-107.

Jyoti, J., \& Sharma, R. D. (2006). Job satisfaction among school teachers. IIMB Management Review, 18, 349-363.

Kim, N., \& Kang, S. W. (2016). Older and more engaged: The mediating role of age-linked resources on work engagement. Human Resource Management, 56(5), 731- 746.

Kirk, B. A., Schutte, N. S., \& Hine, D. W. (2008). Development and preliminary validation of an emotional self-efficacy scale. Personality and Individual Differences, 45, 432-436.

Kokkinos, C. M. (2006). Factor structure and psychometric properties of the Maslach Burnout Inventory - Educators survey among elementary and secondary school teachers in Cyprus. Stress and Health, 22(1), 25-33.

Kokkinos, C. M. (2007). Job stressors, personality and burnout in primary school teachers. The British Journal of Educational Psychology, 77(1), 229-243.

Kristensen, T. S., Borritz, M., Villadsen, E., \& Christensen, K. B. (2005). The Copenhagen Burnout Inventory: A new tool for the assessment of burnout. Work \& Stress, 19(3), 192207.

Küçükoğlu, H. (2014). Ways to cope with teacher burnout factors in ELT classrooms. Procedia - Social and Behavioral Sciences, 116, 2741-2746.

Kyriacou, C. (2001). Teacher stress: Directions for future research. Educational Review, 53, 28-35.

Law, K. S., Wong, C. S., \& Song, L. J. (2004). The construct and criterion validity of emotional intelligence and its potential utility for management studies. Journal of Applied Psychology, 89(3), 483-496.

Locke, E. A. (1976). The nature and cause of job satisfaction. In M. D. Dunnette (Ed.), Handbook of industrial and organizational psychology (pp. 1293-1349). Chicago: Rand McNally. 
Maslach, C., \& Jackson, S. E. (1981). The measurement of experienced burnout. Journal of Organizational Behavior, 2(2), 99-113.

Maslach, C., Jackson, S. E., \& Leiter, M. P. (1996). Maslach Burnout Inventory manual. Palo Alto: Consulting Psychologists Press.

Maslach, C., Schaufeli, W. B., \& Leiter, M. P. (2001). Job burnout. Annual Review of Psychology, 52, 397-422.

Mayer, J. D. (2004). A classification system for the data of personality, psychology and adjoining fields. Review of General Psychology, 8(3), 208-219.

Mayer, J. D., Caruso, D. R., \& Salovey, P. (1999). Emotional intelligence meets traditional standards for an intelligence. Intelligence, 27(4), 267-298.

Mayer, J. D., Caruso, D. R., \& Salovey, P. (2016). The ability model of emotional intelligence: Principles and updates. Emotion Review, 8(4), 290-300.

Mayer, J. D., \& Salovey, P. (1997). What is emotional intelligence? In P. Salovey \& D. J. Sluyter (Eds.), Emotional development and emotional intelligence: Educational implications (pp. 3-34). New York: Harper Collins.

Mayer, J. D., Salovey, P., \& Caruso, D. R. (2000). Competing models of emotional intelligence. In R. J. Sternberg (Ed.), Handbook of human intelligence (pp. 396-422). Cambridge: Cambridge University Press.

Mayer, J. D., Salovey, P., \& Caruso, D. R. (2002). Mayer-Salovey-Caruso Emotional Intelligence Test (MSCEIT): User's manual. Toronto: Multi-Health Systems.

Mayer, J. D., Salovey, P., \& Caruso, D. R. (2004). Emotional intelligence: Theory, findings, and implications. Psychological Inquiry, 15(3), 197-215.

Mayer, J. D., Salovey, P., Caruso, D. R., \& Sitarenios, G. (2003). Measuring emotional intelligence with the MSCEIT v2.0. Emotion, 3, 97-105.

Mérida-López, S., \& Extremera, N. (2017). Emotional intelligence and teacher burnout: A systematic review. International Journal of Educational Research, 85, 121-130.

Mérida-López, S., Extremera, N., \& Rey, L. (2017). Contributions of work-related stress and emotional intelligence to teacher engagement: Additive and interactive effects. International Journal of Environmental Research and Public Health, 14, 1156.

Murray, M. A., \& Atkinson, T. (1981). Gender differences in correlates of job satisfaction. Canadian Journal of Behavioural Science, 13(1), 44-52.

Okojie, M. C. (2011). The changing roles of teachers in a technology learning setting. International Journal of Instructional Media, 38(1), 17-25.

Pena, M., Rey, L., \& Extremera, N. (2012). Life satisfaction and engagement in elementary and primary educators: Differences in emotional intelligence and gender. Revista de Psicodidàctica, 17(2), 341-358.

Penrose, A., Perry, C., \& Ball, I. (2007). Emotional intelligence and teacher self-efficacy: The contribution of teacher status and length of experience. Issues in Educational Research, $17(1), 107-126$. 
Petrides, K. V., \& Furnham, A. (2000). On the dimensional structure of emotional intelligence. Personality and Individual Differences, 29(2), 313-320.

Pitt-Catsouphes, M., \& Matz-Costa, C. (2008). The multi-generational workforce: Workplace flexibility and engagement. Community, Work \& Family, 11, 215-229.

Platsidou, M. (2010). Trait emotional intelligence of Greek special education teachers in relation to burnout and job satisfaction. School Psychology International, 31(1), 60-76.

Platsidou, M., \& Daniilidou, A. (2016). Three scales to measure burnout of primary school teachers: Empirical evidence on their adequacy. International Journal of Educational Psychology, 5(2), 164-186.

Purvanova, R. K., \& Muros, J. P. (2010). Gender differences in burnout: A meta-analysis. Journal of Vocational Behavior, 77, 168-185.

Rey, L., Extremera, N., \& Pena, M. (2016). Emotional competence relating to perceived stress and burnout in Spanish teachers: A mediator model. PeerJ, 4, 1-14.

Rhodes, S. R. (1983). Age-related differences in work attitudes and behavior: A review and conceptual analysis. Psychological Bulletin, 93, 328-367.

Riza, S. D., Ganzach, Y., \& Liu, Y. (2016). Time and job satisfaction: A longitudinal study of the differential roles of age and tenure. Journal of Management, 44(7), 2558-2579.

Roorda, D. L., Koomen, H. M. Y., Spilt, J. L., \& Oort, F. J. (2011). The influence of affective teacher-student relationships on students' school engagement and achievement: A metaanalytic approach. Review of Educational Research, 81(4), 493-529.

Sala, F. (2002). Emotional Competence Inventory: Technical manual. Boston: The Hay Group.

Salovey, P., \& Mayer, J. D. (1990). Emotional intelligence. Imagination, Cognition, and Personality, 9, 185-211.

Schaufeli, W. B., \& Bakker, A. B. (2004). Job demands, job resources, and their relationship with burnout and engagement: A multi-sample study. Journal of Organizational Behavior, 25, 293-315.

Schaufeli, W. B., Bakker, A. B., \& Salanova, M. (2006). The measurement of work engagement with a short questionnaire: A cross-national study. Educational and Psychological Measurement, 66(4), 701-716.

Schaufeli, W. B., Salanova, M., Gonzàlez-Roma, V., \& Bakker, A. B. (2002). The measurement of engagement and burnout: A two sample confirmatory factor analytic approach. Journal of Happiness Studies, 3, 71-92.

Schleicher, D. J., Watt, J. D., \& Greguras, G. J. (2004). Reexamining the job satisfactionperformance relationship: The complexity of attitudes. Journal of Applied Psychology, 89(1), 165-177.

Seibt, R., Spitzer, S., Druschke, D., Scheuch, K., \& Hinz, A. (2013). Predictors of mental health in female teachers. International Journal of Occupational Medicine and Environmental Health, 26, 856-869. 
Simbula, S., Mazzetti, G., \& Guglielmi, D. (2011). Conflicto trabajo-familia, el agotamiento y el compromiso de trabajo entre los docentes: El efecto moderador de trabajo y recursos personales [Work-family conflict, exhaustion and work commitment among teachers: The moderating effect of work and personal resources]. Avances en Psicología Latinoamericana, 29(2), 302-316.

Simbula, S., Panari, C., Guglielmi, D., \& Fraccaroli, F. (2012). Teachers' well-being and effectiveness: The role of the interplay between job demands and job resources. Social and Behavioral Sciences, 69, 729-738.

Skaalvik, E. M., \& Skaalvik, S. (2010). Teacher self-efficacy and teacher burnout: A study of relations. Teaching and Teacher Education, 26, 1059-1069.

Spector, P. E. (1985). Measurement of human service staff satisfaction: Development of the Job Satisfaction Survey. American Journal of Community Psychology, 13, 693-713.

Spector, P. E. (1997). Job satisfaction: Application, assessment, causes and consequences. Thousand Oaks, CA: Sage Publications.

Šarić, M. (2015). Teachers' emotions: A research review from a psychological perspective. Journal of Contemporary Educational Studies, 4, 10-26.

Tharenou, P. (1993). A test of reciprocal causality for absenteeism. Journal of Organizational Behavior, 14(3), 269-287.

Vaezi, S., \& Fallah, N. (2011). The relationship between emotional intelligence and burnout among Iranian ELF teachers. Journal of Language Teaching and Research, 2(5), 11221129.

Van Roosy, D. L., Viswesvaran, C., \& Pluta, P. (2005). An evaluation of construct validity: What is this thing called emotional intelligence? Human Performance, 18, 445-462.

Weaver, C. N. (1974). Correlates of job satisfaction: Some evidence from the national surveys. Academy of Management Journal, 17, 373-375.

Wong, C. S., \& Law, K. S. (2002). The effects of leader and follower emotional intelligence on performance and attitude: An exploratory study. The Leadership Quarterly, 13, 243274.

Yin, H., Lee, J. C. K., Zhang, Z., \& Jin, Y. (2013). Exploring the relationship among teachers' emotional intelligence, emotional labor strategies and teaching satisfaction. Teaching and Teacher Education, 35, 137-145.

Received: November 22, 2019 